\title{
Concentration of Airbone Trace Metals in a Bus Station with a High Heavy-Duty Diesel Fraction
}

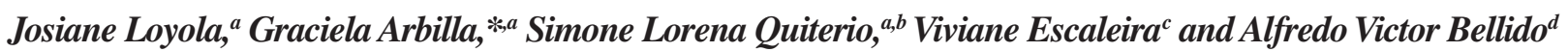 \\ ${ }^{a}$ Departamento de Físico-Química, Universidade Federal do Rio de Janeiro, Centro de Tecnologia, Prédio A, Sala 408, \\ Cidade Universitária, 21949-900 Rio de Janeiro-RJ, Brazil \\ ${ }^{b}$ Centro Federal de Educação Tecnológica de Química de Nilópolis, Unidade Maracanã, Rua Senador Furtado, 121, \\ Maracanã, 20270-020 Rio de Janeiro-RJ, Brazil \\ ${ }^{c}$ Centro Nacional da Pesquisa do Solo, EMBRAPA, Rua Jardim Botânico 1024, 22460-000 Rio de Janeiro-RJ, Brazil

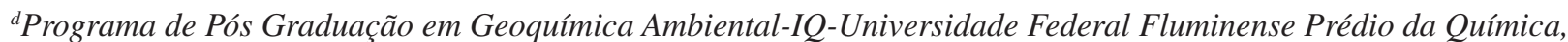 \\ $5^{\circ}$ andar, Valonguinho, 24020-150 Niterói-RJ, Brazil
}

\begin{abstract}
Amostras de material particulado total (MPT) e MP ${ }_{10}$ foram coletadas numa estação de ônibus, no período de agosto de 2006 a fevereiro de 2007. Na área, as únicas fontes importantes de emissão de poluentes são os ônibus, já que os veículos leves representam apenas 1-2\% do fluxo total e não são desenvolvidas outras atividades no local. As concentrações de metais foram determinadas por espectroscopia de emissão por plasma indutivamente acoplado (ICP-OES). Os metais mais abundantes foram $\mathrm{Ca}, \mathrm{Mg}$, $\mathrm{Fe}$ e $\mathrm{Al}$, que correspondem a 50,1\%;24,2\%; 6,5\% e $18,7 \%$, respectivamente, do conteúdo metálico. O Co, $\mathrm{Ni}, \mathrm{Cd}, \mathrm{Cr}$ e $\mathrm{Pb}$ foram encontrados em níveis inferiores ao seu limite de detecção, exceto para algumas poucas amostras. Os fatores de enriquecimento calculados, mostram que o $\mathrm{Zn}$ e o $\mathrm{Cu}$ são devidos provavelmente à composição do combustível e do óleo lubrificante. $\mathrm{O} \mathrm{Ca}, \mathrm{Mg}$ e $\mathrm{Al}$ podem ser atribuídos à resuspensão de poeira, enquanto que o Fe pode ser devido tanto à ressuspensão de poeira como as emissões dos veículos.
\end{abstract}

Total particulate matter (TSP) and $\mathrm{PM}_{10}$ samples were collected in a bus station, in the period of August 2006 to February 2007. Buses are the only significant emission sources in this area once light duty vehicles represent about $1-2 \%$ of total flux and no other activities are developed in the location. Concentrations of metals in the samples were determined by inductively coupled plasma optical emission spectroscopy (ICP-OES). $\mathrm{Ca}, \mathrm{Mg}, \mathrm{Fe}$ and $\mathrm{Al}$ were the most abundant elements and accounted for about $50.1 \%, 24.2 \%, 6.5 \%$ and $18.7 \%$ of the total metal content. $\mathrm{Co}, \mathrm{Ni}, \mathrm{Cd}, \mathrm{Cr}$ and $\mathrm{Pb}$ were under detection limits except for a few samples. Calculated enrichment factors show that $\mathrm{Zn}$ and $\mathrm{Cu}$ are probably due to fuel and oil composition. $\mathrm{Ca}, \mathrm{Mg}$ and $\mathrm{Al}$ may be attributed to dust resuspension while $\mathrm{Fe}$ may be due to both dust resuspension and contribution of vehicles.

Keywords: airborne particulate matter, $\mathrm{PM}_{10}$, trace metal, diesel emissions

\section{Introduction}

Heavy-duty diesel vehicles contribute significantly to air pollution in urban areas. Previous studies conducted by the California Resources Board estimated that, for instance, heavy-duty vehicles account for nearly $80 \%$ of particulate matter (PM) in California. ${ }^{1}$

*e-mail: graciela@iq.ufrj.br
In Brazil, the government regulatory agencies have estimated mobile source emissions for several urban areas. The Metropolitan Area of São Paulo has the largest running fleet in Brazil: roughly 7.3 million passenger cars and commercial vehicles being composed of approximately $6 \%$ of diesel vehicles. ${ }^{2}$ In this region, mobile sources are responsible for about $40 \%$ of inhalable particulate matter emissions $\left(14,000 \mathrm{t}^{\text {year }}{ }^{-1}\right.$ due to diesel engines, 4,900 t year $^{-1}$ due to light-duty vehicles and 9,100 t year ${ }^{-1}$ due to tires of wheels). ${ }^{2}$ Other major sources are secondary 
reactions, i.e., gas-to-particle conversion, condensation and coagulation, which contribute with $25 \%$ of local $\mathrm{PM}_{10}$ emissions. Resuspension of soil and dust generates $25 \%$ of these particles while $10 \%$ is attributable to industrial sources. ${ }^{3}$ The Metropolitan Area of Rio de Janeiro has the second largest running fleet, with nearly 1.5 million vehicles and about $12 \%$ heavy-duty vehicles (mainly buses and trucks) running on diesel. ${ }^{4}$ According to the most recent available official emission inventory, ${ }^{5}$ approximately $76 \%$ of the total air pollution load of $\mathrm{CO}, \mathrm{SO}_{2}, \mathrm{NO}_{\mathrm{X}}$ and $\mathrm{PM}_{10}$ are direct contributions of mobile sources.

Diesel particulate matter consists of an elemental carbon core with a large number of adsorbed substances, such as several organic compounds, sulfates, nitrogen derivatives and metals. The particle size distribution and chemical composition is highly dependable on composition of fuel and lubricating oil, emission control technology, engine type, operating conditions and traffic jams. The properties of Brazilian diesel are presented in Table $1 .{ }^{6}$ No analysis of metal content is required and, to our knowledge, there is no information available in the literature.

National legislation determines the maximum tolerable emissions of diesel vehicles. For new motors, emissions of particulate matter in a current dynamometer test should be less than $0.10 \mathrm{~g} \mathrm{~kW} \mathrm{~h}^{-1}{ }^{7}$ National standards of air quality only determine limits for total particulate matter (240 $\mathrm{ng} \mathrm{m}^{-3}$ for $24 \mathrm{~h}$ and $80 \mathrm{ng} \mathrm{m}^{-3}$ for the annual geometrical mean) and $\mathrm{PM}_{10}\left(150 \mathrm{ng} \mathrm{m}^{-3}\right.$ for $24 \mathrm{~h}$ and $50 \mathrm{ng} \mathrm{m}^{-3}$ for the annual mathematical mean). However, no legislation and no control are done regarding fine particles $\left(\mathrm{PM}_{2.5}\right)$. Literature data obtained for Brazilian cities mainly deals with total suspended particles (TSP) and $\mathrm{PM}_{10}$. Recently, Miranda and Andrade ${ }^{3}$ determined the main characteristics of particles released into the atmosphere of the city of São Paulo, using a microorifice uniform deposit impactor (MOUDI). According to this study, soil-derived elements appeared in the coarse fractions obtained with the impactor, whereas sulfur and black carbon, the latter derived from diesel emissions, were predominant in the fine fraction. Certainly, more studies to assess particulate matter distribution and composition, focused on the fine mode, are necessary.

Several studies have discussed the toxicological effects associated with particle-bound trace metals. ${ }^{8,9}$ The size distribution of atmospheric particle-bound trace metals is crucial in determining their health effects by inhalation. Recent literature data show increased toxicity of particles with decreasing size. ${ }^{10,11}$

As discussed by Valavanidis et al. ${ }^{12}$ the $\mathrm{PM}_{2.5}$ and $\mathrm{PM}_{10}$ levels in urban atmospheres are mainly related to trafficpollutants (both diesel and gasoline vehicles) while coarse particles contain crustal material, and resuspended road dust. $^{13,14}$ The authors reported that $90 \%$ of metals in TSP, $\mathrm{PM}_{10}$ and $\mathrm{PM}_{2.5}$ fractions, collected in the centre of Athens (Greece), were $\mathrm{Fe}, \mathrm{Zn}, \mathrm{Pb}$ and $\mathrm{Cu}$ attributed to traffic, static combustion and crustal matter. These results are in general agreement with the majority of previously reported data.

Recently, trace elements and metals in the ultrafine and accumulation particulate matter modes were measured near a Southern California freeway with approximately $20 \%$ of diesel traffic. Their results confirmed previous studies which showed that the presence of metals in the $18-32 \mathrm{~nm}$ is significantly higher when compared to any other sizes range. ${ }^{15}$

Table 1. Diesel fuel properties for diesel formulations A, B and C which are currently used in Brazil ${ }^{6}$

\begin{tabular}{|c|c|c|c|c|}
\hline \multirow{2}{*}{$\begin{array}{l}\text { Property } \\
\text { Type of Diesel }\end{array}$} & \multirow[t]{2}{*}{ Units } & \multicolumn{3}{|c|}{ Values following ASTM E 29 specifications ${ }^{6}$} \\
\hline & & A & B & $\mathrm{C}$ \\
\hline Sulfur maximum & $\% \mathrm{~m} / \mathrm{m}$ & 1.00 & 0.50 & 0.30 \\
\hline \multicolumn{5}{|l|}{ Volatility } \\
\hline \multicolumn{5}{|l|}{ Distillation } \\
\hline $50 \%$ & ${ }^{\circ} \mathrm{C}$ & $245-310$ & $245-310$ & $245-310$ \\
\hline $80 \%$ & ${ }^{\circ} \mathrm{C}$ & 370 & 370 & 360 \\
\hline Density at $20-24^{\circ} \mathrm{C}$ & $\mathrm{g} \mathrm{cm}^{-3}$ & $0.82-0.88$ & $0.82-0.88$ & $0.82-0.88$ \\
\hline Viscosity $40^{\circ} \mathrm{C}$ & $\mathrm{mm}^{4} \mathrm{~s}^{-1}$ & $1.6-6.0$ & $1.6-6.0$ & $1.6-6.0$ \\
\hline Cetane number & & 40 & 40 & 42 \\
\hline \multicolumn{5}{|l|}{ Contaminants: } \\
\hline Water and Sediments & $\%(\mathrm{v} / \mathrm{v})$ & 0.05 & 0.05 & 0.05 \\
\hline
\end{tabular}

A - used in all regions of Brazil, including Rio de Janeiro; B - used in the cities of Porto Alegre, Curitiba, Belo Horizonte, Recife and Fortaleza; C - used in the cities of Salvador, São Paulo, Santos and Curitiba. 
Direct diesel engine exhaust particles have also received great attention. Using a diesel engine under various driving condition and diesel from Taiwan, it was determine $^{16}$ that the emitted concentrations of crustal elements (such as $\mathrm{Al}, \mathrm{Ca}, \mathrm{Fe}, \mathrm{Mg}$ and $\mathrm{Si}$ ) are much higher than those of anthropogenic elements. Nevertheless, the authors concluded that the contribution of these elements to the ambient environment could be quite significant and different results may be expected for diesel fuel used in other countries.

The goal of this paper is to determine diesel buses emissions of metals in particulate matter, under typical conditions of operation in a bus station, which is poorly ventilated and where the buses move at low speed and park for passenger access. Results are limited since they are strongly affected by vehicle's operating conditions and the quality of diesel fuel. Due to instrumental limitations, only TSP and the $\mathrm{PM}_{10}$ fraction were studied.

\section{Experimental Method}

\section{Sampling site}

Samples were collected in Mayor José Carlos Lacerda bus station, placed in Centenário Quarter, in the city of Duque de Caxias (Figure 1). The city occupies an area of $468.3 \mathrm{~km}^{2}$ and has a population of about 842,890 inhabitants distributed in forty Quarters and four Districts. ${ }^{17}$ The total

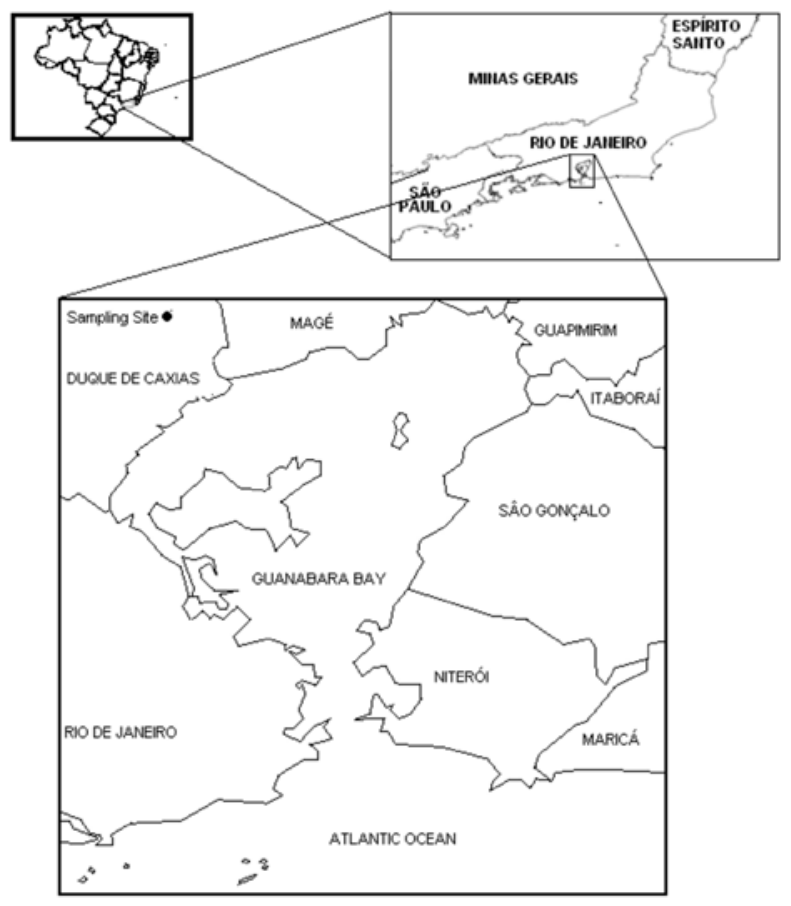

Figure 1. Location of the sampling site, Major José Carlos Lacerda, in the city of Duque de Caxias (Rio de Janeiro Metropolitan Area). number of vehicles in the city is about 160,000 . Presently, $64.7 \%$ of vehicles use gasohol (gasoline with $24 \%$ of ethanol), $11.7 \%$ use neat ethanol, $12.3 \%$ use compressed natural gas (CNG), $2.5 \%$ are flex-fueled cars (gasohol and ethanol) and $8.8 \%$ use diesel. ${ }^{4}$ The city has about 3,000 buses and 690 micro-buses.

The bus station region is a residential area with reduced commercial activity and no industries. The station has one floor $\left(10,621 \mathrm{~m}^{2}\right)$ with 8 platforms for arrivals and departures of urban heavy-duty diesel buses. Each platform has capacity for four buses. Besides movements of arrivals and departures, many vehicles that are waiting for departure keep their motors on. The station makes the confluence for 181 buses from 14 bus lines coming from all other districts of Duque de Caxias (6) and other cities of the Metropolitan Region of Rio de Janeiro (8). The samplers were installed beside one of the platforms at a height of $2 \mathrm{~m}$. The flux of buses is higher during the morning and in the evening. In those periods, the departure interval between buses is nearly five minutes and the frequency of leaving buses in the bus station is less than one minute. Since light duty cars represent about $1-2 \%$ of the total flux, buses are the only significant emission sources. Moreover, no other activities are developed in the location and its surroundings, and no other possible significative sources may be considered. In particular, there are no fastfood restaurants in the area near the platforms.

The bus station has a paved platform and is covered by a roof. Since the sides are opened and the roof is about $10 \mathrm{~m}$ high, it is a well ventilated area.

\section{Sampling}

The selection of the points and the sampling procedure took into account the U.S. Environmental Protection Agency $^{18}$ (EPA) recommendations.

Samplings were performed, in Mayor José Carlos Lacerda bus station on week days using $6 \mathrm{~h}$ sampling periods of time (from 6:00 am to midday). No samplings were performed in the afternoon and at night because the main goal of this work was to identify typical emissions of diesel-powered vehicles. It was not the objective of this study to assess comparisons such as rush-to-non-rush hours or daytime-to-nighttime periods. Furthermore, these comparisons should have been useful to qualify clearly diesel burning but experiments at night were not possible to be performed because of security reasons and availability of the equipment.

TSP and $\mathrm{PM}_{10}$ were collected using high volume samplers (Sibata, model HVC500) and borosilicate glass microfiber filters (Sibata, diameter of $110 \mathrm{~mm}$, thickness of $0.22 \mu \mathrm{m}$ ). The flow rate was aspiration of $500 \mathrm{~L} \mathrm{~min}^{-1}$. 
A total of 66 samples (33 TSP and $33 \mathrm{PM}_{10}$ respectively) were collected, on week days, from August 2006 to February 2007.

\section{Extraction procedure and analysis}

Levels of TSP and $\mathrm{PM}_{10}$ were determined by gravimetry. ${ }^{19-21}$ For analysis of trace metals, the same procedure of our previous studies was followed. ${ }^{19-21}$ Filters were extracted by adding $5 \mathrm{~mL}$ of nitric acid (Merck Suprapur $^{\circledR} 65 \%$ ), $2 \mathrm{~mL}$ of hydrochloric acid (Merck Suprapur $\left.{ }^{\circledR} 36 \%\right)$ and $10 \mathrm{~mL}$ of ultrapure water $\left(18 \mathrm{M} \Omega \mathrm{cm}^{-1}\right.$ of specific resistivity) in a Pyrex ${ }^{\mathrm{TM}}$ tube and let still for $2 \mathrm{~h}$ at $95{ }^{\circ} \mathrm{C}$ in a heating plate. ${ }^{22,23}$ The extracted solution was filtered by using a Whatman $\mathrm{n}^{\circ} 41$ (WH1441-110) filter, completed to $50 \mathrm{~mL}$ with ultrapure water and kept in pre-cleaned polyethylene bottles in the refrigerator until analyses. ${ }^{24,25}$

Filter and reagent blanks were processed following the same treatment. The metal content of the blanks for $\mathrm{Ca}$, $\mathrm{Mg}, \mathrm{Mn}, \mathrm{Fe}, \mathrm{Zn}, \mathrm{Cu}, \mathrm{Co}, \mathrm{Ni}, \mathrm{Al}, \mathrm{Cd}$ and $\mathrm{Pb}$ was less than $5 \%$ of samples average content. For $\mathrm{Cr}$, it represented less than $8 \%$.

Metals were determined by inductively coupled plasma optical emission spectroscopy (ICP-OES) following Method IO-3.4. ${ }^{23}$

Both, detection limits and accuracy for the method were determined following Method IO-3.4. ${ }^{23}$ Detection limits were computed as three times the standard deviation of the distribution of outputs for ten repeated measurements of the standard, which contained no metals. ${ }^{26}$ These limits were calculated as $80 \mathrm{ng} \mathrm{m}^{-3}$ for $\mathrm{Al}$ and $\mathrm{Cr}, 10 \mathrm{ng} \mathrm{m}^{-3}$ for $\mathrm{Zn}, 8 \mathrm{ng} \mathrm{m}^{-3}$ for Fe, Co and $\mathrm{Cu}, 4 \mathrm{ng} \mathrm{m}^{-3}$ for $\mathrm{Mn}, 2 \mathrm{ng} \mathrm{m}^{-3}$ for $\mathrm{Ni}, 0.2 \mathrm{ng} \mathrm{m}^{-3}$ for $\mathrm{Cd}$ and $0.1 \mathrm{ng} \mathrm{m}^{-3}$ for $\mathrm{Pb}$.

The accuracy of the method was evaluated using a standard reference material (SRM, 2783 Air particulate on Filter Media-NIST). Three samples of the reference material were determined in triplicate and the results were compared with the concentration reported in the certificate of analysis. The obtained concentrations differed less than $8 \%$. All samples, as well as SRM, were in the range of the reference material (3-8\%). All samples and SRM were determined in triplicate and a difference lower than $1 \%$ was considered acceptable.

\section{Statistical analysis}

Experimental data were analysed by calculating the Spearman's correlation coefficients using STATISTICA 6.0 (Stat soft) programme. Also principal component analysis (PCA) and cluster analysis (CA), using Euclidian distances and Ward's Method, were performed, as a classification and ordination method.

\section{Results and Discussion}

\section{Particulate matter}

TSP levels, determined by gravimetry, were in the range of 177.6 to $524.2 \mu \mathrm{g} \mathrm{m}^{-3}$. The mean concentration for all samples ( $\mathrm{n}=33$ ) was $335.9 \mu \mathrm{g} \mathrm{m}^{-3}$. Similarly, values for $\mathrm{PM}_{10}(\mathrm{n}=33)$ ranged from 38.6 to $120.6 \mu \mathrm{g} \mathrm{m}^{-3}$, with a mean value of $74.6 \mu \mathrm{g} \mathrm{m}^{-3}$.

The ratios $\mathrm{PM}_{10} / \mathrm{TSP}$ were in the range 0.11 to 0.65 with an average value of 0.24 . Literature data ${ }^{27,28}$ show that most diesel exhaust particle mass is associated with accumulation mode particles, ranging from 0.05 to $0.7 \mu \mathrm{m}$ and centered at about $0.02 \mu \mathrm{m}$. The coarse mode (1-10 $\mu \mathrm{m})$ accounts for $5-20 \%$ of diesel exhaust particle mass, containing accumulation mode particles that have been deposited on cylinder and exhaust system surfaces and are later reentrined. Since in this work only the TSP and PM fractions were studied and clearly the fraction of diameter $>10 \mu \mathrm{m}$ is the most abundant, the main contribution to the studied particulate matter in the bus station is the resuspension of dust.

\section{Levels of trace metals}

Twelve metals were studied in TSP and $\mathrm{PM}_{10}$ samples: $\mathrm{Ca}, \mathrm{Mg}, \mathrm{Mn}, \mathrm{Fe}, \mathrm{Zn}, \mathrm{Cu}, \mathrm{Co}, \mathrm{Ni}, \mathrm{Al}, \mathrm{Cd}, \mathrm{Cr}$ and $\mathrm{Pb}$.

Table 2 shows the mean concentrations as well as standard derivation, minimum and maximum for $\mathrm{Ca}, \mathrm{Mg}$, $\mathrm{Fe}, \mathrm{Zn}, \mathrm{Cu}$ and $\mathrm{Al}$ which were determined in all samples. $\mathrm{Ca}, \mathrm{Mg}$ and $\mathrm{Fe}$ were the most abundant elements and accounted for about $50.1 \%, 24.2 \%, 6.5 \%$ and $18.7 \%$ of the total metal content.

This result agrees with Wang et al. ${ }^{16}$ who reported that $\mathrm{Al}, \mathrm{Ca}, \mathrm{Fe}, \mathrm{Mg}$ and $\mathrm{Si}$ (not determined in the present study) accounted for about $80 \%$ of the total metal content in diesel fuel and in the exhaust of a diesel engine. Aerosol samples from the exhaust of a diesel motor car, in the size range $0.1-2.5 \mu \mathrm{m}$, determined by total reflection X-ray fluorescence presented considerable amounts of $\mathrm{Si}, \mathrm{Ca}$, $\mathrm{Al}, \mathrm{Fe}, \mathrm{Zn}$ and $\mathrm{Mg} .{ }^{29}$

Also, Lough et al. ${ }^{30}$ reported that the most abundant elements determined in $\mathrm{PM}_{10}$ in two tunnels in Milwaukee, USA, were $\mathrm{Fe}, \mathrm{Ca}, \mathrm{Si}, \mathrm{Na}, \mathrm{Mg}, \mathrm{Al}, \mathrm{S}$ and $\mathrm{K}$, which accounted for an average of $94 \%$ of the total $\mathrm{PM}_{10}$ content of 42 measured elements. They were also present in $\mathrm{PM}_{2.5}$ in much lower amounts and were significantly different from zero in $\mathrm{PM}_{2.5}$ in only a few tests. 


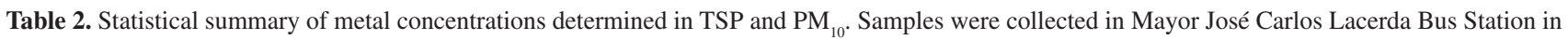
the period of August 2006 to February 2007. Standard deviations (SD), minimum (Min) and maximum (Max) values are also shown

\begin{tabular}{|c|c|c|c|c|c|c|c|}
\hline & & \multicolumn{6}{|c|}{ Concentration $\left(\mathrm{ng} \mathrm{m}^{-3}\right)$} \\
\hline & & $\mathrm{Ca}$ & $\mathrm{Mg}$ & $\mathrm{Fe}$ & $\mathrm{Zn}$ & $\mathrm{Cu}$ & $\mathrm{Al}$ \\
\hline TSP & Mean & 11907 & 5754 & 2597 & 141 & 66 & 4811 \\
\hline \multirow[t]{3}{*}{$(n=33)$} & SD & 3581 & 1784 & 1849 & 110 & 178 & 1815 \\
\hline & Min & 4270 & 1902 & 6 & 0 & 6 & 1423 \\
\hline & Max & 19215 & 8568 & 5715 & 509 & 1049 & 8273 \\
\hline $\mathrm{PM}_{10}$ & Mean & 11145 & 5361 & 1446 & 77 & 26 & 4160 \\
\hline \multirow[t]{3}{*}{$(n=33)$} & SD & 2648 & 1545 & 1625 & 75 & 13 & 1189 \\
\hline & Min & 4270 & 1902 & 218 & Udt & Udt & 1423 \\
\hline & Max & 15548 & 7902 & 5299 & 313 & 51 & 7106 \\
\hline
\end{tabular}

Udt $=$ Under detection limit

The pattern observed in the bus station may be attributed to the influence of several sources such as tail pipe emissions from buses, brake wear, tire wear and resuspended dust. Literature results confirm that diesel fuels and lubrificating oils contain significative amounts of $\mathrm{Ca}, \mathrm{Mg}, \mathrm{Fe}$ and $\mathrm{Zn} .{ }^{16,31,32}$ Lubrificating oils contain trace amounts of $\mathrm{Ti}, \mathrm{Mn}, \mathrm{Co}, \mathrm{Cd}$ and $\mathrm{Pb}$ used as additives. ${ }^{31}$

The exhaust of a 4 cylinders diesel engine, with a rotatory fuel pump and a mechanical injection system was analyzed using the US EPA protocol. The engine was operated with diesel A, currently used in Brazil. Two samples, one of TSP and other of $\mathrm{PM}_{10}$, were collected. In TSP, the following metals were detected: $\mathrm{Ca}(47 \%), \mathrm{Mg}$ (23\%), $\mathrm{Fe}(10 \%), \mathrm{Zn}(0.6 \%), \mathrm{Cu}(0.3 \%)$ and $\mathrm{Al}(19 \%)$. In $\mathrm{PM}_{10}$ the following metals were detected: $\mathrm{Ca}(50 \%), \mathrm{Mg}$ (24\%), $\mathrm{Fe}(6.5 \%), \mathrm{Zn}(0.3 \%), \mathrm{Cu}(0.1 \%)$ and $\mathrm{Al}(19 \%) . \mathrm{Mn}$, $\mathrm{Co}, \mathrm{Ni}, \mathrm{Cd}$ and $\mathrm{Pb}$ were under detection limits.

$\mathrm{Ca}, \mathrm{Mg}, \mathrm{Fe}$ and $\mathrm{Al}$ are major components of crustal materials and soil and are predominantly attributed to resuspension of dust..$^{30}$ It has been previously shown that the dust resuspended from roadways is enriched with many elements emitted from anthropogenic sources. The fact that $\mathrm{Zn}$ and $\mathrm{Cu}$ are present in the samples in higher ratios than those found in crustal materials, while $\mathrm{Ca}, \mathrm{Mg}, \mathrm{Fe}$ and $\mathrm{Al}$ are present in lower levels, indicates that these two elements may have important combustion sources and are enriched in the soil (Table 3). It may be noted that, as previously stated, metal-based oil additives containing $\mathrm{Zn}$ and $\mathrm{Mg}$, anti-wear agents ( $\mathrm{Zn}$ based) and detergents $(\mathrm{Ca}$ and $\mathrm{Mg}$ based) are added to fuels and lubrificating oils, influencing the sizes of emitted particles and their composition. ${ }^{31}$ Also, it was reported that brake wear emissions contain significant amounts of metals, including $\mathrm{Zn}, \mathrm{Cu}, \mathrm{Fe}$ and

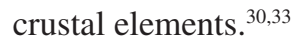

$\mathrm{Mn}, \mathrm{Co}, \mathrm{Ni}, \mathrm{Cd}, \mathrm{Cr}$ and $\mathrm{Pb}$ levels were under detection limits except for a few samples: $\mathrm{PM}_{10}$, one sample presented $129 \mathrm{ng} \mathrm{m}^{-3}$ of $\mathrm{Pb}$, five samples presented concentrations in the range 1.1-9.7 $\mathrm{ng} \mathrm{m}^{-3}$ and another sample contained $6.9 \mathrm{ng} \mathrm{m}^{-3}$ of Ni. For TSP, one sample contained $1.7 \mathrm{ng} \mathrm{m}^{-3}$ of $\mathrm{Cd}, \mathrm{Ni}$ and $\mathrm{Cd}$ is present in batteries. It is worth noting that the extraction procedure, mainly the final sample volume, may have a negative contribution to the detection

Table 3. Relative concentration of each metal in TSP and $\mathrm{PM}_{10}$ samples (first and second columns). Typical crust concentration in units of ng $\mathrm{m}^{-3}$ (third column) and relative concentration of each metal in the earth's crust (fourth column). Enrichment factors (EF) for each metal in TSP and $\mathrm{PM}_{10}$ samples (two last columns) calculated using $\mathrm{Al}$ as reference

\begin{tabular}{|c|c|c|c|c|c|c|}
\hline Metals & $\begin{array}{c}\% \text { of metal } \\
\text { in TSP }\end{array}$ & $\begin{array}{c}\% \text { of metal } \\
\text { in } \mathrm{PM}_{10}\end{array}$ & Crust concentration & $\begin{array}{c}\text { EF } \\
\text { (in TSP) }\end{array}$ & $\begin{array}{c}\mathrm{EF} \\
\text { (in } \mathrm{PM}_{10} \text { ) }\end{array}$ & $\begin{array}{c}\% \text { of metal } \\
\text { in crust }\end{array}$ \\
\hline $\mathrm{Ca}$ & 47.0 & 50.2 & $4.9 \times 10^{13}$ & 4.2 & 4.5 & 22.3 \\
\hline $\mathrm{Mg}$ & 22.7 & 24.1 & $3.2 \times 10^{13}$ & 3.1 & 3.1 & 14.5 \\
\hline $\mathrm{Fe}$ & 10.3 & 6.5 & $5.7 \times 10^{13}$ & 0.8 & 0.5 & 25.9 \\
\hline $\mathrm{Zn}$ & 0.6 & 0.3 & $7.9 \times 10^{10}$ & 30.6 & 19.3 & 0.0 \\
\hline $\mathrm{Cu}$ & 0.3 & 0.1 & $3.7 \times 10^{10}$ & 30.0 & 13.9 & 0.0 \\
\hline $\mathrm{Al}$ & 19.0 & 18.7 & $8.2 \times 10^{13}$ & 1.0 & 1.0 & 37.3 \\
\hline
\end{tabular}


Table 4. Estimated trace element dry deposition fluxes in Mayor José Carlos Lacerda Bus Station $\left(\mathrm{F}_{\mathrm{d}}\right)$. Dry settling velocities $\left(\mathrm{V}_{\mathrm{d}}\right)$ are literature data ${ }^{34-36}$

\begin{tabular}{|c|c|c|c|c|c|c|}
\hline $\mathrm{PM}_{10}$ & $\mathrm{Ca}$ & $\mathrm{Mg}$ & $\mathrm{Fe}$ & $\mathrm{Zn}$ & $\mathrm{Cu}$ & $\mathrm{Al}$ \\
\hline Mean concentration $\left(\mathrm{ng} \mathrm{m}^{-3}\right)$ & 11907 & 5754 & 2597 & 141 & 66 & 4811 \\
\hline Dry settling velocity $\left(\mathrm{V}_{\mathrm{d}}\right)\left(\mathrm{cm} \mathrm{s}^{-1}\right)$ & 2.0 & 2.0 & 2.0 & 0.1 & 0.1 & 2.0 \\
\hline Dry deposition Flux $\left(\mathrm{F}_{\mathrm{d}}\right)\left(\mathrm{mg} \mathrm{m}^{-2} \mathrm{yr}^{-1}\right)$ & 60078 & 29035 & 13103 & 36 & 17 & 24275 \\
\hline TSP & $\mathrm{Ca}$ & $\mathrm{Mg}$ & $\mathrm{Fe}$ & $\mathrm{Zn}$ & $\mathrm{Cu}$ & $\mathrm{Al}$ \\
\hline Mean concentration $\left(\mathrm{ng} \mathrm{m}^{-3}\right)$ & 11145 & 5361 & 1446 & 77 & 26 & 4160 \\
\hline Dry settling velocity $\left(\mathrm{V}_{\mathrm{d}}\right)\left(\mathrm{cm} \mathrm{s}^{-1}\right)$ & 2.0 & 2.0 & 2.0 & 0.1 & 0.1 & 2.0 \\
\hline Dry deposition Flux $\left(\mathrm{F}_{\mathrm{d}}\right)\left(\mathrm{mg} \mathrm{m}^{-2} \mathrm{yr}^{-1}\right)$ & 168703 & 81149 & 21893 & 58 & 20 & 62965 \\
\hline
\end{tabular}

of these metals. Eventually, using smaller volumes, they would be determined in concentrations higher than the detection limit.

\section{Enrichment factors}

Enrichment factors (EF) were also calculated using $\mathrm{Fe}$ as reference and the expression:

$\mathrm{Ef}_{\mathrm{X}}=(\mathrm{X} / \mathrm{Ref})_{\text {air }} /(\mathrm{X} / \mathrm{Ref})_{\text {crust }}$

The interpretation of EF is based on the fact that metals originated from well defined sources, such as the earth's crust can be distinguished from other metals derived from anthropogenic processes. ${ }^{34-36}$ Since crustal metals are also present in direct exhausts emissions from the diesel motors, the choice of a reference material is rather difficult.

When using $\mathrm{Al}$ as reference, which is traditionally considered a soil tracer, enrichment factors for $\mathrm{Zn}$ and $\mathrm{Cu}$ in the range from 13.8 to 30.6 are obtained, confirming the possibility of anthropogenic sources.

\section{Trace metal dry deposition fluxes}

Dry deposition fluxes were calculated using the equation:

$\mathrm{F}_{\mathrm{d}}=\mathrm{C}_{\mathrm{i}} \times \mathrm{V}_{\mathrm{d}}$

where $F_{\mathrm{d}}$ is the dry deposition flux, $C_{i}$ the trace metal geometric mean concentration taken from a prolonged sampling period and $\mathrm{V}_{\mathrm{d}}$ is the elemental settling velocity. ${ }^{37}$ The deposition processes include gravitational settling, impaction and diffusion, ${ }^{38}$ which are dependent upon wind speed, humidity, viscosity and surface roughness. A range of settling velocities have been applied to dry deposition flux calculations in the past, these were determined by a number of approaches including mass-size distributions in the aerosol population, usually evaluated from cascade impactor data. ${ }^{39-41}$ For $\mathrm{Zn}$ and $\mathrm{Cu}$, a mean value of $0.1 \mathrm{~cm} \mathrm{~s}^{-1}$ was applied, and for $\mathrm{Ca}, \mathrm{Mg}, \mathrm{Fe}$ and $\mathrm{Al}$ a mean value of $2 \mathrm{~cm} \mathrm{~s}^{-1}$ was adopted. These values fall close to the $V_{\mathrm{d}}$ range given in other studies ${ }^{42-44}$ (and references there in). It should be emphasized, however, that the flux calculations might vary by approximately one order of magnitude due to the uncertainties in $V_{d}$.

Calculated values are presented in Table 4. Dry deposition fluxes are higher for $\mathrm{Ca}, \mathrm{Mg}, \mathrm{Al}$ and $\mathrm{Fe}$, in decreasing order, due to their high concentration and settling velocities. Fluxes for $\mathrm{Zn}$ and $\mathrm{Cu}$ are three orders of magnitude lower.

\section{Statistical analysis}

Spearman correlation coefficients, calculated using the individual concentrations $(n=33$ for TSP and $n=33$ for $\mathrm{PM}_{10}$ ), are presented in Table 5.

Table 5. Spearman's correlation factors calculated for metals in TSP and $\mathrm{PM}_{10}$ samples collected of metals in Mayor José Carlos Lacerda Bus Station (significant values at $95 \%$ of confidence limit are in bold)

\begin{tabular}{lcccccc}
\hline $\mathrm{TSP}$ & $\mathrm{Ca}$ & $\mathrm{Mg}$ & $\mathrm{Fe}$ & $\mathrm{Zn}$ & $\mathrm{Cu}$ & $\mathrm{Al}$ \\
\hline $\mathrm{Ca}$ & 1.0 & & & & & \\
$\mathrm{Mg}$ & $\mathbf{0 . 9 5}$ & 1.0 & & & & \\
$\mathrm{Fe}$ & $\mathbf{0 . 6 5}$ & 0.58 & 1.0 & & & \\
$\mathrm{Zn}$ & 0.49 & 0.39 & $\mathbf{0 . 7 9}$ & 1.0 & & \\
$\mathrm{Cu}$ & -0.33 & -0.20 & -0.18 & -0.16 & 1.0 & \\
$\mathrm{Al}$ & $\mathbf{0 . 9 2}$ & $\mathbf{0 . 8 8}$ & $\mathbf{0 . 8 4}$ & $\mathbf{0 . 6 8}$ & -0.42 & 1.0 \\
\hline $\mathrm{PM}$ & $\mathrm{Ca}$ & $\mathrm{Mg}$ & $\mathrm{Fe}$ & $\mathrm{Zn}$ & $\mathrm{Cu}$ & $\mathrm{Al}$ \\
\hline $\mathrm{Ca}$ & 1.0 & & & & & \\
$\mathrm{Mg}$ & $\mathbf{0 . 8 4}$ & 1.0 & & & & \\
$\mathrm{Fe}$ & 0.38 & 0.11 & 1.0 & & & \\
$\mathrm{Zn}$ & 0.40 & 0.18 & $\mathbf{0 . 9 2}$ & 1.0 & & \\
$\mathrm{Cu}$ & 0.50 & 0.35 & $\mathbf{0 . 6 9}$ & $\mathbf{0 . 7 1}$ & 1.0 & \\
$\mathrm{Al}$ & $\mathbf{0 . 8 4}$ & $\mathbf{0 . 7 9}$ & $\mathbf{0 . 6 6}$ & $\mathbf{0 . 6 5}$ & $\mathbf{0 . 6 7}$ & 1.0 \\
\hline
\end{tabular}



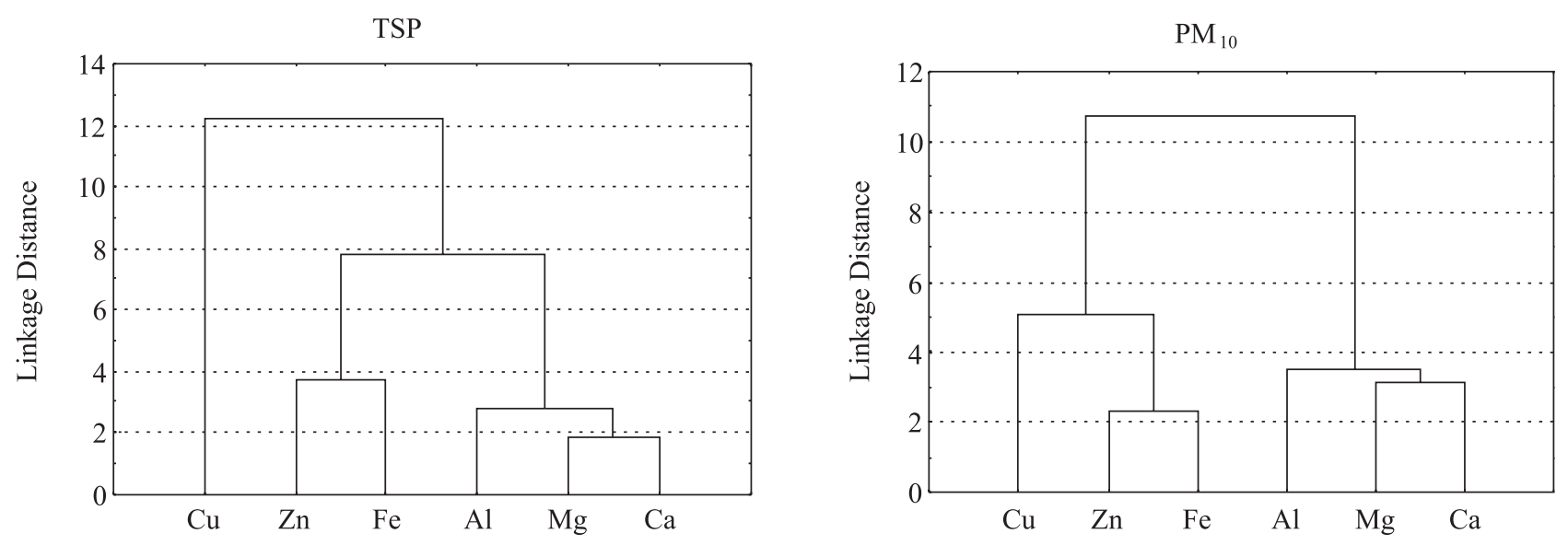

Figure 2. Cluster analysis, at 95\% confidence limit, for TSP and $\mathrm{PM}_{10}$ samples collected at Major José Carlos Lacerda Bus Station.

High correlations $(0.88-0.92)$ were obtained for $\mathrm{Ca}$, $\mathrm{Mg}, \mathrm{Fe}$ and $\mathrm{Al}$ in TSP samples. Furthermore, $\mathrm{Zn}$ and $\mathrm{Fe}$ show a high correlation (0.79) while the value for $\mathrm{Zn}$ and $\mathrm{Cu}$ is very low. A similar result is shown in Figure 2 in which the cluster analysis is displayed. $\mathrm{Al}, \mathrm{Mg}$ and $\mathrm{Ca}$ are grouped in the same sub-group, as well as $\mathrm{Zn}$ and $\mathrm{Fe}$. The five elements are in the same group in the dendogram of Figure 2.

Besides, the principal component analysis shows three groups. Component 1, which accounts for $66.8 \%$ of the total variance, contains $\mathrm{Fe}$ and $\mathrm{Zn}$. $\mathrm{Ca}, \mathrm{Mg}$, and $\mathrm{Al}$ are included in component 3 ( $96.0 \%$ of total variance).

Data for $\mathrm{PM}_{10}$ also show a high correlation between $\mathrm{Ca}, \mathrm{Mg}$ and $\mathrm{Al}$ with Spearman correlation coefficients in the range of 0.79-0.84 (see Table 5). Fe and $\mathrm{Zn}$ also show high correlation (0.92) and $\mathrm{Zn}-\mathrm{Cu}$ has a coefficient of 0.71. These data are consistent with the dendogram displayed in Figure 2: two clusters are obtained, one grouping $\mathrm{Cu}, \mathrm{Zn}$ and $\mathrm{Fe}$ and the other containing $\mathrm{Al}, \mathrm{Mg}$ and $\mathrm{Ca}$.

Principal components analysis leads to two factors: factor 1, (which represents $65.6 \%$ of variance) groups $\mathrm{Fe}$, $\mathrm{Zn}$ and $\mathrm{Cu}$, and factor 2 contains $\mathrm{Ca}, \mathrm{Mg}$ and $\mathrm{Al}$ accounts for $89.9 \%$ of total variance.

When comparing TSP and $\mathrm{PM}_{10}$ data, it can be seen that $\mathrm{Ca}, \mathrm{Mg}$ and $\mathrm{Al}$ are highly correlated in both particulate matter fractions. As previously stated, they are major components of crustal materials and are indicative of the significant contribution of dust resuspension to particulate matter contribution.

As suggested by the enrichment factors, $\mathrm{Zn}$ and $\mathrm{Cu}$, which may have an important anthropogenic contribution, only show a good correlation in $\mathrm{PM}_{10}$ Fe also shows a good correlation with $\mathrm{Zn}$, manly in $\mathrm{PM}_{10}$. These results may be explained considering that it was reported that brake emissions contain significant amounts of metals, including $\mathrm{Zn}, \mathrm{Cu}, \mathrm{Fe}$ and crustal elements. ${ }^{30,33}$

\section{Conclusions}

The results of this study showed that diesel vehicles significantly contribute to the emissions of $\mathrm{Ca}, \mathrm{Mg}, \mathrm{Zn}$ and $\mathrm{Cu}$. The pattern observed may be attributed to the contribution of several sources such as tail pipe emissions, brake wear, tire wear and resuspended dust. The analysis of the exhaust of a diesel motor confirmed that these metals are emitted by diesel combustion. Oil additive also contains trace quantities of these metals, while brake wear emissions contain significant amounts of $\mathrm{Zn}, \mathrm{Cu}$ and crustal elements.

Due to instrumental limitations, only the TSP and $\mathrm{PM}_{10}$ fractions were determined but, clearly, the characterization of trace metals in the fine and ultrafine ranges is important due to the toxicological impacts of some of the metals studied.

\section{Acknowledgments}

The study was funded in part by National Council for Technological and Scientific Development (CNPq) and Research Foundation of the State of Rio de Janeiro (FAPERJ). We would like to thank the collaboration of LMT, Federal University of Rio de Janeiro, in particular Albino José Kalab Leiroz, Nauberto Rodrigues Pinto, Pedro Paulo Pereira, Pedro Henrique Leite dos Santos, Renan de Souza and Marcos Dufles for providing the facilities to perform the sampling of the diesel motor exhaust, and to Marcos Menezes and Luiz Carlos de Oliveira, FIOCRUZ, for lending the high volume samplers.

\section{References}

1. Lev-On, M.; Letavec, C.; Uihlein, J.; Alleman, T.; Lawson, D.; Vertin, K.; Thompson, G.; Gautam, M.; Wayne, W. S.; Zielinska, B.; Sagebiel, J.; Chatterjee, S.; Hallstrom, K.; Journal of Fuels and Lubricants 2003, 111, 220. 
2. http://www.cetesb.sp.gov.br, accessed in August 2007.

3. Miranda, R. M.; Andrade, M. F.; Atmos. Environ. 2005, 39, 6188.

4. http://www.detran.rj.gov.br, accessed in August 2007.

5. Loureiro, L. N.; MSc Dissertation, Federal University of Rio de Janeiro, Brazil, 2005. http://www.ppe.ufrj.br/ppe/production/ tesis/lnloureiro.pdf, accessed in November 2007.

6. http:/ www.anp.gov.br, accessed in April 2007.

7. http://www.feema.rj.gov.br/proconve-promot.asp, accessed in March 2008.

8. Carter, J. D.; Ghio, A . J.; Samet, J. M.; Devlin, R. B.; Toxicol. Appl. Pharmacol. 1999, 146, 180.

9. Ghio, A. J.; Stonehuerner, J.; Dailey, L. A.; Carter, J. D.; Inhalation Toxicol. 1999, 11, 37.

10. Kreyling, W.G.; Semmler-Behnke, M.; Moller, W.; J. Aerosol Med. 2006, 19, 74.

11. Karakoti, A. S.; Hench, L. L.; Seal, L.; J. Miner. Metals Mater. Soc. 2006, 58, 7782 .

12. Valavanidis, A.; Fiotakis, K.; Vlahogianni, T.; Bakeas, E. B.; Triantafillaki, S.; Chemosphere 2006, 65, 760.

13. Vallius, M.; Janssen, N. A.; Heinrich, J.; Hoek, G.; Ruuskanen, J.; Cyrys, J.; Van Grieken, R.; de Hartog, J. J.; Kreyling, W. G.; Pekkanen, J.; Sci. Total Environ. 2005, 33, 147.

14. Park, S. S.; Kim, Y. J.; Chemosphere 2005, 59, 217.

15. Nhtziachristos, L.; Ning, Z.; Geller, M. D.; Sheesley, R. J.; Schauer, J. J.; Sioutas, C.; Atmos. Environ. 2007, 41, 5684.

16. Wang, Y. F.; Huang, K. L.; Li, C. T.; Mi, H. H.; Luoc, J. H.; Tsaid, P. J.; Atmos. Environ. 2003, 37, 4637.

17. http://www.duquedecaxias.rj.gov.br/web/cgi/cgilua.exe/sys/ start.htm, accessed in April 2007.

18. http://www.epa.gov/epaoswer/hazwaste/test/pdfs/3550c.pdf, accessed in July 2006.

19. Quiterio, S. L.; Arbilla, G.; Silva, C. R. S.; Escaleira, V.; Atmos. Environ. 2004, 38, 32.

20. Quiterio, S. L.; Arbilla, G.; Escaleira, V.; Silva, C. R. S.; Maia L. F. P. G.; Bull. Environ. Contam. Toxicol. 2004, 72, 916.

21. Loyola, J.; Almeida Junior, P. B.; Quiterio, S. L.; Sousa, C. R.; Arbilla, G.; Arch. Environ. Contam. Toxicol. 2006, 51, 93.

22. Fernandez, A. J.; Ternero, M.; Barragán, F. J.; Jiménez, J. C.; Chemosphere 2000, 2, 123.

23. Method IO-3.4. Determination of Minerals in Ambient Particulate Matter using Inductively Coupled Plasma (ICP) Spectroscopy. US EPA, Washington, 1999.

24. Serrano, E.; Beceiro, E. López, P.; Prada, D.; Quim. Anal. (Barcelona) 1996, 15, 38.

25. Beceiro-Gonzalez, E.; Andrade-Garda, J. M.; Serrano-Velasco, E.; Lopez-Mahía, P.; Sci. Total Environ. 1997, 196, 131.
26. Boss, C. B.; Fredeen, K. J. Concepts, Instrumentation, and Techniques in Inductively Coupled Plasma Optical Emission Spectrometry, $2^{\text {nd }}$ ed, Perkin Elmer Corp: Norwalk, 1999.

27. Zielinska, B.; Exp. Toxicol. Pathol. 2005, 57, 31.

28. Kittelson, D. B.; J. Aerosol Sci. 1998, 29, 575.

29. Weber, S.; Hoffmann, P.; Ensling, J.; Dedic, A. N.; Weinbruch, S.; Miehe, G.; Gutlich, P.; Ortner, H. M.; J. Aerosol Sci. 2000, $31,987$.

30. Lough, R.G.; Buckley, L. J.; Werner, F. E.; Quinlan, J. A.; Edwards, K. P.; Fish. Oceanogr. 2005, 14, 241.

31. Lin, M. C. H.; Ayoko, G. A.; Morawska, L.; Ristovski, Z. D.; Jayaratne, E. R.; Fuel 2007, 86, 1831.

32. Weckwerth, G.; Atmos. Environ. 2001, 35, 5525.

33. Garg, B. D.; Cadle, S. H.; Mulawa, P. A.; Groblicki, P. J.; Laroo, C.; Parr, G. A.; Environ. Sci. Technol. 2000, 34, 4463.

34. Caroli, S.; La Torre, F.; Petrucci, F.; Violante, N.; Element Speciation in Inorganic Chemistry, Wiley-Interscience: New York, 1996.

35. Ure, A. M.; Davidson, C. M.; Chemical Speciation in the Environment, Blackie Academic \& Professional: London, 1995.

36. Cheng, M. T.; Lin, Y. C.; Chio, C. P.; Wang, C. F.; Kuo, C. Y.; Chemosphere 2005, 61, 1439.

37. Pereira, P. A. P.; Lopes, W. A.; Carvalho, L. S.; Rocha, G. O.; Bahia, N. C.; Loyola, J.; Quiterio, S. L.; Escaleira, V.; Arbilla, G.; de Andrade, J. B.; Atmos. Environ. 2007, 41, 7837.

38. Duce, R. A.; Liss, P. S.; Merril, J. T.; Atlas, E. L.; Buat-Menard, P.; Hickes, B. B.; Miller, J. M.; Prospero, J. M.; Arimoto, R.; Church, T.; M., Ellis, W.; Galloway, J. N.; Hansen, L.; Jickells, T. D.; Knap, A. H.; Reinhardt, K. H.; Schneider, B.; Soudine, A., Tokos, J. J.; Tsunogai, S.; Wollast, R., Zhou, M.; Global Biogeochem. Cycles. 1991, 5, 193.

39. Dulac, F.; Buat-Menard, P.; Ezat, U.; Melki, S.; Bergametti, G.; Tellus 1989, 41B, 362.

40. Ottley, C. J.; Harrison, R. M.; Atmos. Environ. 1993, 27A, 685.

41. Spokes, L. J.; Jickells, T. D.; Jarvis, K.; Mar. Chem. 2001, 76, 319.

42. Herut, B.; Nimmo, M.; Medway, A.; Chester, R.; Krom, M. D.; Atmos. Environ. 2001, 35, 803.

43. Migon, C.; Journel, B.; Nicolas, E.; Atmos. Environ. 1997, 31, 889.

44. Rojas, C. M.; Injuk, J.; Van Grieken, R. E.; Laane, R. W.; Atmos. Environ. 1993, 27A, 251.

Received: July 7, 2008 Web Release Date: July 17, 2009 